\title{
The Evaluation of Feed-in Tariff Models for Photovoltaic System in Thailand
}

\author{
Kangsadan Sagulpongmalee ${ }^{1}$, and Apichit Therdyothin ${ }^{2}$ \\ ${ }^{1}$ Division of Energy Technology, School of Energy, Environment and Materials, King Mongkut's University of Technology Thonburi, 126 \\ Pracha Uthit Road, Bang mod, Thung khru, Bangkok 10140, Thailand. \\ ${ }^{2}$ Division of Energy Management Technology, School of Energy, Environment and Materials, King Mongkut's University of Technology \\ Thonburi, 126 Pracha Uthit Road, Bang mod, Thung khru, Bangkok 10140, Thailand.
}

\begin{abstract}
Thailand is targeted to reach 6,000 MW of total installed PV capacity by 2036. Feed-in tariff (FIT) was one of the most successful PV mechanisms of Thailand for promoting PV generated electricity. The evaluation of the FIT models for PV in Thailand which was designed 3 models such as premium price FIT model (Adder) in the first FIT policy to motivate attention on investment in PV power plant. After that used fixed price FIT model for PV groundmounted and front-end loaded FIT model for solar rooftop. In addition to, Thailand has project-specific tariff design which FIT rates are differentiated tariff payment levels by technology, capacity size, and quality of the resource. As result of FIT policies, the PV installation is 1,287 MW of cumulative capacity in 2014. Furthermore, the financial evaluation of FIT for PV project in Thailand found that Net Present Value (NPV) 32.97 million Baht, Internal Rate of Return (IRR) $13.22 \%$, payback period 8.86 years and $\mathrm{B} / \mathrm{C}$ ratio was 1.66 which must be implemented in conjunction with other financial support measures such as low interest loans, tax benefits, etc. The several incentives to promote PV in Thailand especially FIT shown as PV projects are to be profitable and incentives to investors.
\end{abstract}

\section{Introduction}

Renewable energy (RE) become important issue because of the conventional energy source is limited. At the end of 2013, the rate of depletion of world's fossil energy in term of reserves-to-production ratio $(\mathrm{R} / \mathrm{P})$ of oil, natural gas, and coal were 53.3, 55.1, and 113 years of global production, respectively [1]. This limitation and depletion of fossil energy reserves included with the increasing energy consumption, development of RE resources. The policy planners have tried to fill out how to promote RE to generate the energy through barriers such as the economics, institutional, political and legislative. Feed-in Tariff (FIT) was one of the most successful renewable mechanisms for promoting large-scale energy markets that offered necessary to attract inventor [2]. FIT program is an incentive plan which provides investors with a set electricity price from RE sources that is fed into the power grid [3]. As of early 2015, FIT policies have been adopted by 73 countries at the national level and in 35 states/provinces [4]. Many countries in Europe (France, Germany, Greece, Italy, Spain and the U.K.) have implemented of FIT support polices for different sized PV systems and the different ways of implementing FIT support policies in the various countries can lead to significantly different results [5]. Especially, the Italian $\mathrm{PV}$ market has experienced a progress in the PV market after the first mechanism of feed-in tariffs was promoted in 2005 and Italy has become one of the leading markets for PV power plants currently which the amount of PV installations in Italy was driven by the FIT explicitly [6]. In Malaysia has been introduced FIT in 2011 which has greatly improved the prospect of the RE resources, especially for $\mathrm{PV}$, the solar $\mathrm{PV}$ panel instalments in Malaysia is also contributed by the efforts from the business and banking sector [7].

In Thailand, the final energy consumption in 2014 was about 75,804 ktoe and the energy demand of national had to depend on energy imports, was 69,248 ktoe [8] which effect to strengthen energy security in domestic. Currently, Photovoltaic (PV) is one of the fastest growing renewable energy technologies which Thailand has potential extremely. Thai government has introduced various incentives measures especially FITs were considered to promote PV to success the target since 2006. The National Energy Policy Council (NEPC) resolutions ratified Alternative Energy Development Plan (AEDP 2015) to establish renewable energy target (6,000 MW for solar PV target) which be the challenge target [9]. Thailand's feedin tariff program has already been an attractive RE support mechanism but could be awareness in planning and regulatory framework for FIT [2]. Therefore cost of FIT project will include in electricity bill of ratepayer so FIT pricing is extremely important. The purpose of this paper is to evaluate and analysis the FIT models for photovoltaic 
system of Thailand after implementation of the FIT policies several years ago.

\section{Remuneration of feed-in tariffs policy Page layout}

The first feed-in tariff (FIT) was introduced in 1978 which signed on the National Energy Act of the US. The primary objective of FIT policies is to expand of RE generation. In generally, purchase agreements are typically offered within contracts ranging from $10-25$ years and the payment levels offered for each kilowatt-hour which there are several designs and can be differentiated by technology type or fuel type, project size, resource quality, and project location to reflect actual project costs [10]. In addition to, Couture and Gagnon [11] have suggested the different ways to structure the remuneration of FIT tariff policy that varying on seven models around the world which have been classified into two broad categories comprised of dependent or independent from the actual electricity

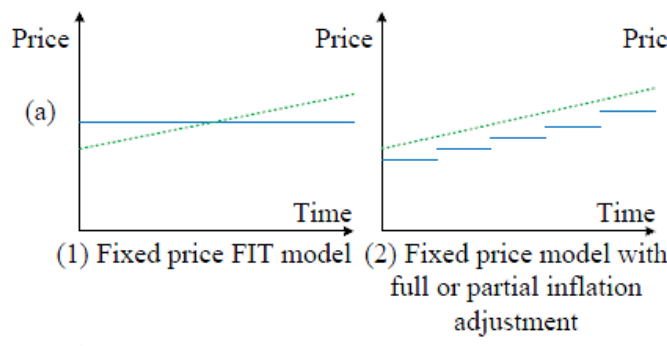

market price. The market-independent FIT policies (Figure 1. (a)) have four options. The first and most basic option is the fixed price FIT model which price fixed for the duration of the contract. The second FIT policy is the fixed price model with full or partial inflation adjustment. The third is the front-end loaded FIT model which higher payments are offered in the early years than the later years. The fourth is the spot market gap model which actual FIT payment composed of the gap between the spot market price and the required FIT price. The other category consists of the three different types of the marketdependent FIT policies (Figure 1. (b)). The first is premium price FIT model which the premium price remuneration paid over the retail or market electricity price at the time. The second is the variable premium FIT model which includes both caps and floor into the FIT structure which the total remuneration is premium rate plus with the current market price. The third is the percentage of the retail price FIT model which establishes a fixed percentage of the retail electricity price.

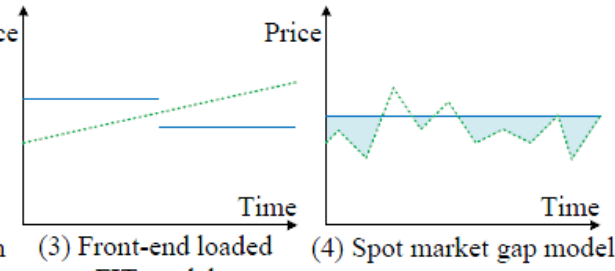
FIT model

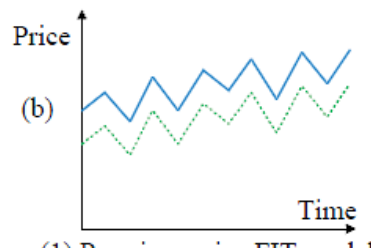

(1) Premium price FIT model

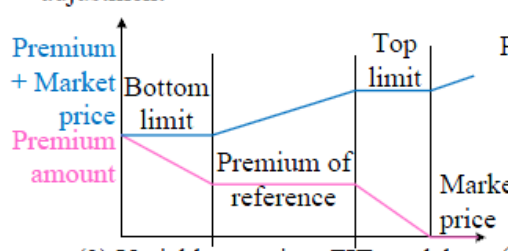

(2) Variable premium FIT model FIT ……... Retail price

\author{
(3)
}

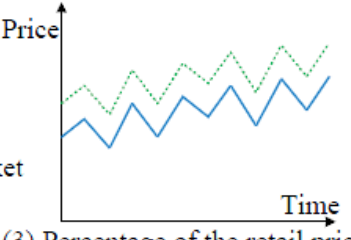

3) Percentage of the retail price

Figure 1. Models of feed-in tariff policy [11]

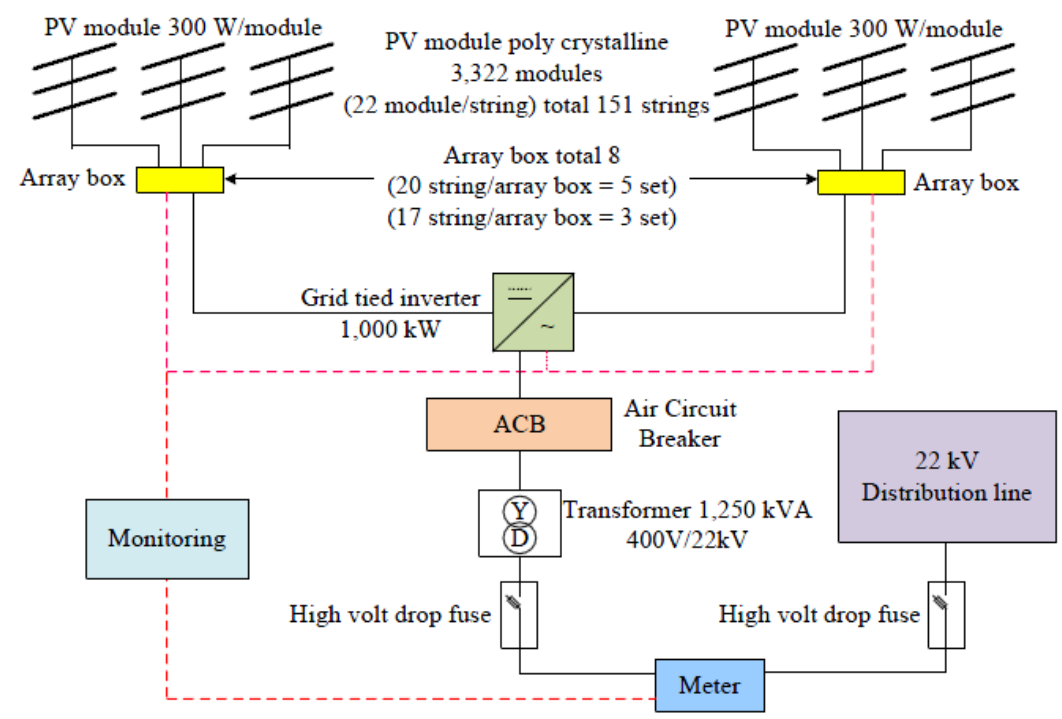

Figure 2. Layout of PV power plant system in Thailand capacity $1 \mathrm{MW}$.

\section{Situation of PV in Thailand}

Thailand as the country locates near the equator therefore; the majority of areas in Thailand have high sunlight 
intensity. The maximum solar radiation is $20-24 \mathrm{MJ} / \mathrm{m}^{2}$ day during April and May and average daily solar radiation about $18.2 \mathrm{MJ} / \mathrm{m} 2$-day or $5.6-6.7 \mathrm{kWh} / \mathrm{m}^{2}$-day. Thailand's electricity sector has evolved from a government monopoly to a semi-unbundled structure by enhanced single buyer. The Installation of PV power plant in Thailand, also called solar farm, has become the main PV installation. In 2014, Thailand PV installation is 1,287 MW of cumulative capacity which increased $823 \mathrm{MW}$ in 2013. The most of PV power plants were built with imported PV components, mainly from Taiwan (45\%), Japan $(27 \%)$ and China (13\%) and domestic has 5\% of total PV system installation. The inverters of PV power plants were imported from United States (53\%), Germany (26\%) and Japan (10\%) and the local inverter company has $8 \%$ of total PV system installation [12]. The Layout of solar farm system in Thailand capacity $1 \mathrm{MW}$ as shown in Figure 2.

\section{The evaluation of feed-in Tariff models for PV in Thailand}

The PV growth in Thailand is driven and managed by the National Energy Policy Council (NEPC) [13]. The Renewable Energy Development Program (REDP) (20082022) was approved on 16 January 2009 by NEPC which set the PV target in 2022 of $500 \mathrm{MW}$. On 30 November 2011, the NEPC resolution approved the new plan, the 10Year Alternative Energy Development Plan (AEDP) (2012-2021) to replace REDP which aims to increase the share of RE to be $25 \%$ of total final energy consumption in 10 years and PV's target was 2,000 MW in 2021 [14]. Furthermore, the NEPC also has been revised AEDP and increased PV target several times, including on 16 July 2013, 3,000 MW [15] and on 22 October 2014, 3,800 MW which comprised 2,800 MW solar farms, $800 \mathrm{MW}$ solar farms on government land or managed by agricultural cooperatives, and $200 \mathrm{MW}$ of PV rooftop [16] and the latest, on 17 September 2015, NEPC approved the Alternative Energy Development Plan 2015-2036 (AEDP 2015) comprised PV 6,000 MW [17].

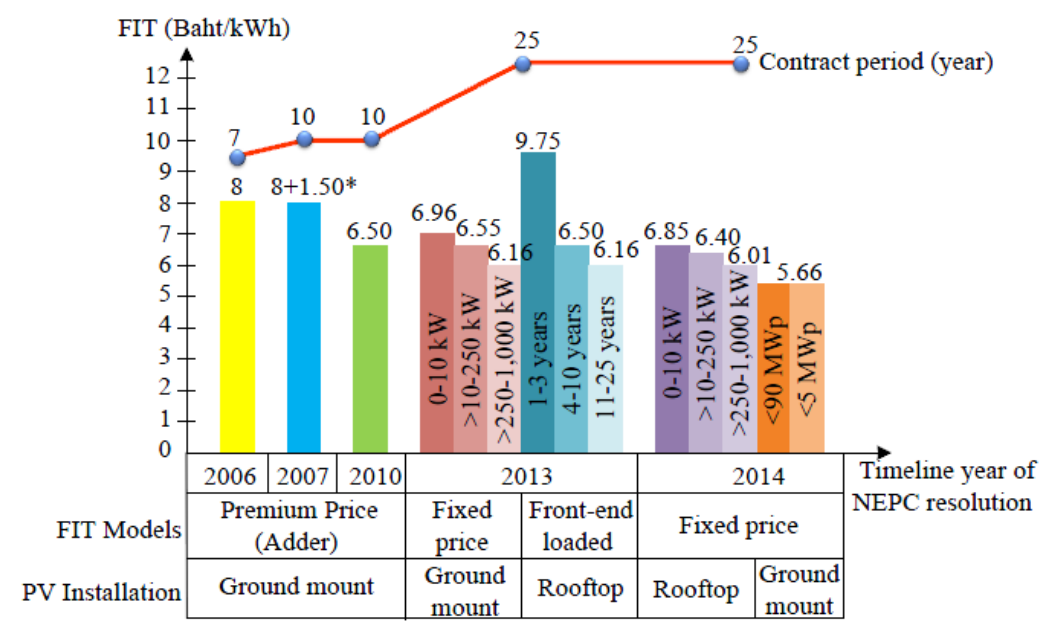

Figure 3. Evaluation of FIT rates and models in Thailand [2, 9, 14-16]

\subsection{Evaluation of feed-in Tariff rates of Thailand}

Thailand is one of the first countries in the ASEAN to implement FIT mechanism which adopted by the Thai Cabinet in 2002 and implemented premium FIT (Adder) in 2006 [2]. The Adder paid on top of the retail electricity price to guarantee attractive purchasing rates. In 2010, higher Adder was paid in the three southernmost provinces which have experienced political unrest. Through the PV world market prices have decreased [18] and Ministry of Energy representatives has raised concerns regarding transparency and consistency [2], and significantly reduced approval rates of new applications as result the FIT of Thailand has cut the rate down in 2011.

The NEPC resolution in 2013 approved to switch from a premium-price FIT payment to a fixed-price FIT payment for ground mount plant and front-end loaded FIT payment for solar rooftop (Figure 3.). Currently, The NEPC progressed on 14 May 2015, a total PV of 1,558
MW are already installed on grid and total in the pipeline amounts to 2,819 MW [19]. By the first RE plan, premium price FIT model can create confidence and profitable for investors are extremely FIT rate of $8 \mathrm{Baht} / \mathrm{kWh}$ added with retail electricity price about $3.50 \mathrm{Baht} / \mathrm{kWh}$ so the investors will receive total price of $11.50 \mathrm{Baht} / \mathrm{kWh}$ which is the highest rate but contract period of 7 and 10 years. After that, FIT rate adjusted reduction to $6.50 \mathrm{Baht} / \mathrm{kWh}$ followed to global PV market price. The next, FIT model changed to fixed price FIT model to PV ground mount and front-end loaded FIT model for solar rooftop but increase contract period to 25 years.

\subsection{Evaluation of feed-in Tariff designs of Thailand}

FITs in Thailand has several project-specific tariff designs which are differentiated tariff payment levels by technology, capacity size of the installation, and the project location. 


\subsubsection{Evaluation of Differentiation by Technology or Fuel Type}

FITs Thailand were designed to offer different tariffs by fuel type and technology. In 2006, premium FIT were biomass, wind, hydro, and PV of $0.3,2.5,0.4-0.8$, and 8 Baht/kWh respectively [2]. In 2013, FIT's Thailand was separated PV supporting into two technologies were ground mount and rooftop [15].

\subsubsection{Evaluation of Tariff Differentiation by Project Size}

Thailand differentiates by project size in its FIT policy for PV. In 2013, FIT has divided size for PV ground mount into three groups were $0-10 \mathrm{~kW}(6.96 \mathrm{Baht} / \mathrm{kWh}), 10-250$ $\mathrm{kW}$ (6.55 Baht/kWh), and 250-1000 kW (6.16 Baht/kWh) [15] which provided the highest tariff for the smallest capacity PV installations.

\subsubsection{Evaluation of Tariff Differentiation by Project Location}

Differentiated by project location, Thailand offers a higher payment of installed PV rooftop for the residential or building more than PV ground mount. Furthermore, PV installation in southernmost provinces and off-grid areas were advanced higher FIT $1.50 \mathrm{baht} / \mathrm{kWh}$ [20].

\subsection{Evaluation of PV project of Thailand's feed-in Tariff policy}

The evaluation of Feed-in Tariff for PV system in Thailand for installation capacity plant $1 \mathrm{MW}$ which have financial assumption such as initial investment 49.9 million Baht (Table 1.), operating and maintenance cost increased $12 \%$ per year from initial O\&M cost, plant factor $16 \%$, deterioration of income $0.8 \%$ per year of income on first year, interest rate $6 \%$, paying loan back in 10 years, Debt-to-Equity Ratio (70:30) and contract period 25 years. According to those parameters, FIT rate for PV ground-mounted is $5.66 \mathrm{Baht} / \mathrm{kWh}$, found that the solar PV power plant will receive the Net Present Value (NPV) 32.97 million Baht, the Internal Rate of Return (IRR) $13.22 \%$, the payback period 8.86 years and the Benefit/Cost $(\mathrm{B} / \mathrm{C})$ ratio of 1.66 excluding income from carbon credits and including implemented in conjunction with other promotion measures such as low interest loans, tax benefits, etc.

Table 1. The initial investment for PV power plant in Thailand of capacity $1 \mathrm{MW}$ in 2014.

\begin{tabular}{|l|c|c|c|}
\hline \multicolumn{1}{|c|}{ Description } & $\begin{array}{c}\text { Material cost } \\
\text { (Baht) }\end{array}$ & $\begin{array}{c}\text { Labour cost } \\
\text { (Baht) }\end{array}$ & $\begin{array}{c}\text { Total } \\
\text { (Baht) }\end{array}$ \\
\hline 1. Electrical work & $29,190,725$ & $1,583,661$ & $30,774,386$ \\
\hline $\begin{array}{l}\text { 2. Civil and } \\
\text { architectural work }\end{array}$ & $5,638,000$ & 558,200 & $7,896,200$ \\
\hline 3. Sanitary work & 590,000 & 69,150 & 659,150 \\
\hline $\begin{array}{l}\text { 4. Operation } \\
\text { construction }\end{array}$ & - & $3,615,500$ & $3,615,500$ \\
\hline $\begin{array}{l}\text { 5. Import tax and } \\
\text { Value Added Tax }\end{array}$ & - & - & $4,891,294$ \\
\hline
\end{tabular}

\begin{tabular}{|c|c|c|c|}
\hline (Vat 7\%) & & & \\
\hline 6. Others & - & - & $2,100,000$ \\
\hline Total & & & $49,936,530$ \\
\hline
\end{tabular}

\section{Conclusions}

Thailand has successful in promoting PV which important attractive mechanism is FIT policy. The PV's growth in Thailand is driven by the energy policy of the government which is managed by the National Energy Policy Council (NEPC). In 2006, Thailand began to adopt this approach in FIT policy and in 2014, Thailand PV installation is 1,287 MW of cumulative capacity which higher than other countries in ASEAN. Thailand's FIT policy has been designed to differentiated tariff payment levels depending to project-specific comprise differentiated by technology, capacity size of the installation, and location of the project. In addition, the remuneration of FIT policy has been applied that varying on three models such as premium price FIT model, fixed price FIT model, and front-end loaded FIT model. According to several FIT designed which are appropriate to the geographical conditions of Thailand and as a result currently, Thailand's PV installed capacity increased significantly. The evaluation of PV power plant in Thailand using FIT policy found that the projects are capable of profitable but be implemented in conjunction with other financial support measures such as low interest loans, tax benefits, etc. Although PV power plant project will not make extremely profits for investors which FIT rate is expected to reduce in the future but solar power is a clean and environmentally friendly and energy security of the country therefore should be considered for promoting the PV project with reasonable FIT rate of each country.

\section{Acknowledgements}

The authors would like to thank to the thesis committees including Warunee Tia (Assoc. Prof.) and Janthana Kunchornrat (Ph.D.), School of Energy, Environment and Materials, King Mongkut's University of Technology Thonburi for any kinds of advice and cooperation.

\section{References}

1. BP Statistical Review of World Energy. BP Statistical Review of World Energy June 2014, Accessed May 1, 2015 at:

$<$ https://www.bp.com/content/dam/bp/pdf/Energyeconomics/statistical-review-2014/.pdf $>$

2. S. Tongsopit, C. Greacen, Renew Energ. 60, $439-$ 445 (2013)

3. K. Kyoung-Kuk, L.Chi-Guhn.Energ Pol. 49, 192-203 (2012)

4. REN21. Renewables 2015 Global Status Report, Accessed August 3, 2015 at: $<$ http://www.ren21.net/wp-content/uploads/2015 /07/REN12-GSR2015_Onlinebook_low1.pdf $>$

5. A.Campoccia, L.Dusonchet, E.Telaretti, and G.Zizzo. Sol Energ. 107, 530-542 (2014) 
6. A.Marco, D.Umberto. Appl Energ, 135, 721-729 (2014)

7. S. L. Wong, N. Norzita, A. Tuan, I. M. Inuwa, Renew Sustain Energ Rev. 41, 42-52 (2015)

8. Department of Alternative Energy Development and Efficiency, Ministry of Energy, Energy Balance of Thailand, Accessed October 1, 2015 at: < http://www4.dede.go.th/dede/images/stories/stat_dede /sit_58.pdf>

9. National Energy Policy Council Resolutions 1/2014 on 15 August 2014 (in Thai). Accessed August 3, 2015 at: < http://www.eppo.go.th/nepc/kpc/kpcNCPO-1.html>

10. T. D. Couture, K. C. C. Kreycik, E. Williams. $A$ Policymaker's Guide to Feed-in Tariff Policy Design: National Renewable Energy Laboratory, Colorado, (2010)

11. T. Couture, Y. Gagnon, Energ Pol. 38, 955-965 (2010)

12. Department of Alternative Energy Development and Efficiency: Ministry of Energy. Thailand PV status Report 2012-2013. Accessed August 3, 2015 at: < http://www4.dede.go.th/dede/images/stories/jum_circ ular_55/PV_Status_Report_eng_final.pdf $>$

13. Energy Policy \& Planning Office: Ministry of Energy. The National Energy Policy Council (NEPC). Accessed August 3, 2015 at: < http://www.eppo.go.th/doc/doc-manage.html>

14. National Energy Policy Council Resolutions 6/2011 on 30 November 2011 (in Thai). Accessed August 3, 2015 at: < http://www.eppo.go.th/nepc/kpc/kpc139.htm>

15. National Energy Policy Council Resolutions $2 / 2013$ on 16 July 2013 (in Thai). Accessed August 4, 2015 at: $<$ http://www.eppo.go.th/nepc/kpc/kpc-145.html $>$

16. National Energy Policy Council Resolutions $1 / 2014$ on 22 October 2014 (in Thai). Accessed August 5, 2015 at: < http://www.eppo.go.th/nepc/kpc/kpc146.html>

17. Department of Alternative Energy Development and Efficiency: Ministry of Energy. Alternative Energy Development Plan: AEDP 2015. Accessed October 6, 2015 at: < www.dede.go.th/ download/files/PPT_AEDP2015.pdf $>$

18. National Energy Policy Council Resolutions 2/2010 on 28 June 2010 (in Thai). Accessed August 1, 2015 at: < http://www.eppo.go.th/nepc/kpc/kpc-N2.html >

19. National Energy Policy Council Resolutions $2 / 2015$ on 14 May 2015 (in Thai). Accessed September 16, 2015 at: < http://www.eppo.go.th/nepc/kpc/kpcN2.html $>$

20. National Energy Policy Council Resolutions 4/2007 on 4 June 2007 (in Thai). Accessed July 10, 2015 at: < http://www.eppo.go.th/nepc/kpc/kpc-113.htm> 